\title{
Social Support to Reduce Disease- Related Stigma: Lesson Learned from Corona Virus Disease-19
}

\author{
Marizka Khairunnisa $^{a}$, Cati Martiyana ${ }^{b}$, Diah Yunitawatic, Leny Latifah ${ }^{d}$, Yusi Dwi \\ Nurcahyani ${ }^{\mathrm{e}}$, b,c,d,e Magelang Health Research and Development Center, Ministry of \\ Health, Indonesia; Email: marizkakhairunnisa@gmail.com
}

Stigma associated with COVID-19 is intense. One of the factors that can help in reducing stigma is social support. This research aims to explore stigma, efforts to deal with stigma, and support for people diagnosed with COVID-19. The research design is qualitative research using phenomenological approach and analyzed using thematic content analysis. Data collection was carried out in July-August 2020 through telephone interviews with eleven positive COVID-19 informants. Of the eleven informants who were COVID-19 positive, eight of them experienced stigma. Nonetheless, both stigmatized and non-stigmatized informants received social support. Friends and family are the main sources of support for stigmatized informants. Meanwhile, for non-stigmatized informants, the main support was obtained from the community. The results showed that social support can reduce or even eliminate stigma. The social support that comes from the community is the most influential in reducing stigma. From this research, public support is more efficient compared to individual support. When the community provides support together, the risk of stigma can be reduced. The results of this study can be used to prevent stigmatizing behavior by strengthening social support, especially community support.

Key words: stigma, social support, COVID-19 
International Journal of Innovation, Creativity and Change. www.ijicc.net

Volume 15, Issue 9, 2021

\section{Introduction}

Since its emerging and declared as pandemic by the world health organization (WHO) on March 2020, coronavirus disease 2019 (COVID-19) has become a pandemic that is unceasingly being tackled by the world community. If we look at the number of cases in 223 countries, as many as 102,942,987 people were confirmed positive (WHO, 2020). COVID-19 cases in Indonesia have reached 1,099,687 cases as of February 2, 2021 (Satgas Penanganan COVID-19, 2020).

The stigma of COVID-19 and psychological conditions are consistent and dominant topics discussed by the public, notably when the number of cases is high. COVID-19 has an impact on mental health, such as fear, anxiety, and correlated with stigma (Dye et al., 2020). Ahmad Dar's research found a high enacted and externalized stigma in COVID-19 survivors (Dar et al., 2020). Brewis stated that the long-term effects of stigma on the physical and mental health of patients are predicted to persist, even though vaccines and other solutions are currently available (Brewis, Wutich, \& Mahdavi, 2020).

Several previous studies have explored the stigma of society towards patients of infectious diseases. Those who are stigmatized are vulnerable to social avoidance or rejection, poor treatment-seeking behavior, and even physical violence (Centers for Disease Control and Prevention, 2020). As for the case of COVID-19, it also found that COVID-19 has caused embarrassment, exposed confidentiality, delay or refusal of treatment, non-compliance with action and treatment, physical and psychological stress, and self-stigma (Imran et al., 2020).

Stigma is vulnerable to people diagnosed with COVID-19, their families, and also health workers who treat COVID-19 patients (Fawaz \& Samaha, 2020). During the pandemic, those who tested positive for COVID-19 experience social discrimination and stigma, limited social interaction, and psychological impact (Bhatt et al., 2020). At the beginning of the pandemic in Indonesia, stigma occurred with the refusal of burials of bodies infected with COVID-19 in several regions and cases of health nurses being expelled from boarding houses because of their job (Kompas, 2020). This shows that Indonesian people did not fully understand the COVID-19 epidemic, including transmission, management and prevention (Sulistiadi, Rahayu, \& Harmani, 2020).

Social support can be a strategy to overcome stigma and is an important source of strength for people who experience it (Schmitt, Branscombe, Postmes, \& Garcia, 2014). The result of research in China shows that people who experience internalized stigmatization feel anxiety, depression, and shame. Social support is an effective way to reduce the effect. When the level of social support is high, the impact of internalized stigmatization on mental health is tenure, 
International Journal of Innovation, Creativity and Change. www.ijicc.net

Volume 15, Issue 9, 2021

whereas when social support is at a low level, the impact appears stronger (J. Li, Liang, Yuan, \& Zeng, 2020).

Similarly, study conducted for a more specific circle also shows comparable results. The results of research on students in China who have experienced mental health impacts due to the COVID-19 pandemic such as stress, depression, anxiety, and also leading to suicidal ideation demonstrates that social support and mindfulness issues are protective factors against mental health problems (S. Sun, Goldberg, Lin, Qiao, \& Operario, 2021). For the health workers, COVID-19 pandemic increases the risk of mental health problems because of the high risk of being exposed and getting stigma. Social support is an important factor in overcoming psychological problems and also prevent the impact of a high workload on health workers (Janitra, Melastuti, Yusuf, Fadhilah, \& Wibawa, 2021).

This study aims to explore the stigma, efforts to deal with it, and support for people diagnosed with COVID-19, both health workers and non-health workers who live in DKI Jakarta, Banten, West Java, Central Java, East Java, and DIY in the new normal era.

\section{Method}

This qualitative research is part of a study on stigma and COVID-19, entitled "Mental Health, Behavior, and Stigma". The research was conducted in Java, covering the provinces of DKI Jakarta, Banten, West Java, Central Java, East Java, and DIY. The research begins with quantitative data collection, and then continues with qualitative data collection on selected prospective informants according to the criteria specified: people who have or are currently diagnosed with COVID-19. Qualitative data collection uses a phenomenological approach to find out information about the phenomenon of stigma and support received by positive cases of COVID-19.

Data collection was carried out in July-August 2020 through telephone interviews and was recorded using a recording device attached to the telephone. Interviews use semi-structured interview guidelines to explore the stigma experienced by positive informants on COVID-19. Interviews were conducted by a team of researchers who had equated perceptions about the purpose and objectives of the interview, with research backgrounds in the fields of sociology, anthropology, psychology, and public health. The informant has no previous relationship with the interviewer. Interviews were conducted once and lasted about 30-45 minutes per informant. The entire interview process was conducted and recorded after obtaining the informants' consent. The informant has the right to stop the interview at any time during the interview process. The confidentiality of all informants is guaranteed. 
International Journal of Innovation, Creativity and Change. www.ijicc.net

Volume 15, Issue 9, 2021

The selection of informants used purposive sampling where the informant has filled out a questionnaire online and has been or is being diagnosed with COVID-19. Informants who cut off the telephone while being interviewed were deemed unwilling to become informants. Qualitative data collection was halted when the information obtained was judged to be saturated, that is, no new information was obtained about the stigma experienced by the informants. In this study, eleven positive informants of COVID-19 were interviewed consist of seven health workers and four non health workers.

Data analysis was carried out using thematic content analysis, by identifying themes that emerged from the interview data. The recording of the interview results was transcribed, then read and coded manually by three people from the interviewing team. The coding that has been made is included in sub-categories and categories to be identified in the themes.

This research has received ethical approval from the Ethics Commission, National Institute of Health Research and Development Ministry of Health number: LB. 02.01 / 2 / KE.386 / 2020.

\section{Results}

\section{Self-Stigma of Informants}

The self-stigma experienced by the informants included the feelings of distrust, rejection, sadness, self-blame, fear of being a source of infection, and worry that the community would be considered them as carrier of the virus. One of the informants was in denial. Despite being willing to carry out self-isolation, the informant believed that his current condition was not due to COVID-19. Compared to non health care informants, some health workers said they were not too worried when tested positive for COVID-19 because they felt they had knowledge about what to do.

\section{Social Stigma Experienced by Informants}

Almost all informants experienced social stigma in the form of avoidance, rejection, and unpleasant behavior and speech from others. Neighbors immediately evacuated, closed the access road to the informant's house, showed a face of disgust every time they passed the informant's house, and even their close friends decided to stay away. One of the informant had experienced rejection by the residents, who did not want him to return home after completing his isolation at the hospital. 
International Journal of Innovation, Creativity and Change. www.ijicc.net

Volume 15, Issue 9, 2021

"I haven't come home (from the hospital). Some people said that my house was demolished by the community, I was reported dead." (MU, non health worker)

For health care informants, stigma does not solely come from the general public. This also comes from fellow health workers, who are blaming and in avoidance. One health care informant who was infected with COVID-19 from the patient was considered to have taken a careless act for not wearing a complete personal protective equipment (PPE). Meanwhile, other informant experienced rejection when they returned to work because some colleagues still considered him as a source of infection.

\section{Social Stigma Experienced by People Surround the Informant}

Stigma does not only affect informants, but also family and close people who are not infected with COVID-19. The form of stigma experienced is almost similar, in the form of avoidance, exclusion, rejection, and discrimination because of people's fear of being infected. A family is not served when it comes to buying groceries. The wife of another informants was asked by residents to participate in meetings from outside the room. The children of the informant also experienced stigma because neighbors considered them as virus carriers.

Discrimination was experienced by $\mathrm{Tr}$ informant's brother-in-law. He was not allowed by his boss to enter the furniture factory where he works, before taking the swab test at his own expense. Informant Tr considered this to be disproportionate because his brother-in-law lived in different village so there was even no contact with him. After the informant asked the village head for help, Tr's brother-in-law was allowed to return to work, but he was placed in a room separated from other employees. Informant Rah was experienced discriminatory treatment when the news about his grandmother who died from COVID-19 was not broadcast in the local mosque, even though it had been reported to the officer. Meanwhile, neighbor of informant F, a shop owner who had been on the list of close contacts and had to undergo a swab test, was asked to close the shop by the community even though the swab test showed negative results.

"My brother-in-law is healthy, has no symptom, and doesn't even live at the same house with me. But still, you can't come to work! It concerns a person's financial need. And after being allowed to come to work, he was exiled. Although he is not necessarily positive, it still scares people. " (Tr, health worker)

The stigma of labeling was experienced by the informant, where the community was labeled Tr's family as the "corona family". Labeling was also given to residents who live in the same 
International Journal of Innovation, Creativity and Change. www.ijicc.net

Volume 15, Issue 9, 2021

village as informant $\mathrm{F}$. There was a warning to residents to stay away and not make contact with residents from village $\mathrm{X}$, where informant $\mathrm{F}$ lives.

\section{Informant Who Did Not Experience Stigma}

From the results of this study, there were three informants who did not experience stigma. Two of them work as health workers, while one informant is a non-health worker. Health care informants who did not get a stigma did not tell their neighbors about their positive status of COVID-19 and only tell friends and family. This decision was made because they felt that they had carried out self-isolation in a disciplined manner at home and did not want to make neighbors feel uncomfortable. Meanwhile, non-health worker informant who did not get the stigma received full support from the community, immediately after reporting the positive status of COVID-19 to the local community.

\section{Disclosure of COVID-19 Positive Status}

The negative stigma and rejection from the community have caused some informants to initially decide to keep their status as secret. In addition, the informant also felt worried that it would become a burden to his relatives, thus they only told his family. An informant, who intends to only tell his close family, found that his positive status had spread widely and caused fear in the community where he lived. Even so, some informants stated that it was not an easy thing to keep a COVID-19 positive status a secret because every case had to be reported to related parties.

In this study, there were informants who were afraid to report to his local community or even chose not to tell their neighbors about his self-isolation. An informant admitted that he did not unveil to his doctor about the travel history of his parents to the red zone of COVID-19. Other informants cover up their status for fear of being shunned by their families, neighbors and society.

“...Only to my husband. My big family didn't know. Neighbors also didn't know at all. They know after the completion of my isolation because I blurted it out... I am afraid of their reaction... "(US, health worker)

Not all informants hide their positive COVID-19 status and do not mind if others find out. Informant openness is shown by reporting to officials when they find positive swab results and being open to the public regarding the positive status of COVID-19 they have experienced. 
International Journal of Innovation, Creativity and Change. www.ijicc.net

Volume 15, Issue 9, 2021

"If I am silent then I do a wrong act. If, for example, I convey it, the consequences that I must accept, I am ready to accept. If I am to be exiled or else, I am mentally ready" (AY, non-health worker)

\section{Social Support Received by Informants}

Among eleven informants who were positive for COVID-19, eight of them experienced stigma. This stigma was not only aimed at the informant, but also experienced by the their family and closest people. On the other hand, all informants also received support from family, neighbors, religious leaders, leaders and / or co-workers. Although informant X received a stigma from his fellow health workers, at the same time, he also received support from his fellow health workers. Similarly, informant US, received support from leaders and colleagues at the hospital where the he works.

The forms of support received vary both moral and material support. There were supports in the form of delivery of food, groceries, vitamins, toys and children's needs, as well as moral support through WhatsApp chat and video calls so that they did not feel lonely and always think positively during their treatment and self-isolation. Not spreading confusing information about the condition of informants is one form of perceived support from colleagues. Meanwhile, the support received from the office was in the form of granting permission to be off duty from the office during the recovery period. One of the informants is allowed to work from home with the support of facilities from the office where the informant works. Other support is in the form of financial support for self-isolation at the hotel after the informant is allowed to leave the hospital.

"The only person who came to my house was the kyai (religious leader). To give support. In the mosque there are many congregations, then kyai provides support, and that's when the community realizes, oh it's okay then to accept me.. " (MU, non health worker)

Meanwhile, positive COVID-19 informants who do not experience stigma receive support from family, friends and neighbors. Two out of three informants who do not experience the stigma are doctors and were at self-isolation at home. Informant E said that full support was obtained from the hospital where he worked so that the informant did not experience difficulties in accessing health services. This was recognized as one of the informants' advantages as a doctor. Other support was felt in the form of prayers and delivery of basic necessities from fellow informants.

Informant Ay, a non health worker, said that apart from support from family and friends, the informant received full support from the community in the neighborhood. At first the informant was worried that he would experience a negative stigma from the community after reporting the positive status of COVID-19 to the local community chief. However, after the local community 
International Journal of Innovation, Creativity and Change. www.ijicc.net

Volume 15, Issue 9, 2021

chief found out about the news, he gathered all neighbors to provide support by sending foodstuffs for the family during the 14 days of self-isolation. Neighbors always ask about the informants' health conditions and provide motivation via WhatsApp or phone calls.

"Previously I imagined it would be like what is on TV, thankfully the impact was different" (Ay, non-health worker)

Informant Ay admitted that from all of the community's support, possibly one or two neighbors still have a negative opinion of COVID-19 patient. However, not once informant Ay receive stigma. There were no road access closures, as well as excessive guarding and warnings that made the informant and his family feel uncomfortable.

\section{DISCUSSION}

Stigma is one of the important issues during the COVID-19 pandemic. The stigma associated with disease is occured because this disease is highly contagious, potentially deadly, and there is no known cure (Brewis et al., 2020). Similar to what happened in the early days of the pandemic in Indonesia, the public felt frightened because of the very fast transmission and the risk of death from Covid-19, while there was no treatment and vaccine for prevention.

The result showed that eight of the eleven informants experienced stigma. Feelings of sadness, denying that they have been infected, being considered by the community as carriers of the disease are some of the self-stigma experienced by informants when they first learned that they had been infected with COVID-19. The same results were found in Sun's research, which states that in the early stages after being infected, patients experience feelings of fear, rejection, and also stigma (N. Sun et al., 2021). The self-stigma experienced in the early stages of COVID-19 is significant to understand because it is related to acceptance or rejection of the disease. Providing emotional support in the early stages of the disease is crucial and is one of the main needs of the patient to help facilitate their treatment and healing (N. Sun et al., 2021).

Stigmatization can lead to rejection, avoidance and distancing (Stangl et al., 2019). In this study, several forms of stigma were experienced in the form of rejection, discrimination, labeling, exclusion, and avoidance. One of the informants experienced a refusal to re-integrate with the community after being stated negative. COVID-19 survivors initially had difficulty socializing in society because they experienced exclusion (Dar et al., 2020). This is because the public's fear of COVID-19 is still considerable, intensified with no right information. A person who is undergoing a period of quarantine tends to experience stigma and rejection from the community (Brooks et al., 2020). On one hand, self-quarantine or isolation is one way to prevent the spread 
International Journal of Innovation, Creativity and Change. www.ijicc.net

Volume 15, Issue 9, 2021

the virus but on the other hand, it can increase the risk of stigma (Saeed et al., 2020). The result of the study in Jordan shows that most respondents agree that both patients and people who come into contact with patients should be isolated and have limited mobility (Abuhammad, Alzoubi, \& Khabour, 2020).

Health worker informants get stigma from their fellow health workers, in the form of avoidance, exclusion, being blamed for not taking care of themselves, and being considered a source of infection. This shows that stigma can be experienced by anyone, and done by anyone, including health workers. Fear and panic about COVID-19 causes health workers, who are considered to have more knowledge about how the disease is transmitted still also stigmatize (Grover, Singh, Sahoo, \& Mehra, 2020).

Stigma is not only experienced by positive COVID-19 informants, but also those closest to the informant such as family, relatives, friends, and neighbors. The same findings from research in India stated that positive cases of COVID-19 and their families, whether tested positive or not, tended to experience stigma from society (Imran et al., 2020). The community labels the informant's family as the virus carrier and the corona family. The stigma attached to certain groups is often associated with the spread of the virus (Turner-Musa, Ajayi, \& Kemp, 2020). The closest person of the informants considered potential to spread the virus. This reaction also occurred in China in the early days of the pandemic, where students from Wuhan experienced stigma because they were considered a potential source of infection ( $\mathrm{H}$. Li et al., 2020). This results show that the public still has a wrong view regarding the transmission of COVID-19 and generalizes that all those who have kinship with informants are at risk of transmitting COVID-19 so it must be avoided.

The community labels the informant's family as the carrier of the virus and the corona family. Families who do not live in the same house and have no contact with the informant are not allowed to come to work. One resident on the close contact list was urged to close the shop even though the swab test came back negative. All residents who come from the same village as the informant must temporarily be shunned because they have the potential to spread the virus. This reaction also occurred in China in the early days of the pandemic, where as many as 41 percent of students from Wuhan experienced stigma and discrimination because they were considered a potential source of infection (H. Li et al., 2020).

A small proportion of participants decided to keep secret from several groups for fear of facing stigma or protecting family members from discrimination. Several studies have shown that stigma and discrimination is a factor that influences a person's decision not to be open about the disease they suffer (Amo-Adjei, 2016). Meanwhile, research on COVID-19 positive patients who 
were being treated at the hospital shows that they have high scores regarding concerns about public reaction and openness of status (Imran et al., 2020).

One of the informants believed that he was not infected with COVID-19 even though laboratory tests showed positive results for COVID-19. Rejection reactions to certain diseases are one of the efforts made by patients to avoid stigma (Brewis et al.,2020). Informants who chose not to disclose their status assumed that the price they had to pay when they were open about their status was greater than the possible impact of hiding their status. Being open about status is important so that someone can receive social support. But on the other hand, the fear of being stigmatized also causes someone to hide their status. Several informants were open about their COVID-19 positive status since beginning with several reasons such as government policies, social responsibility, to get support, and fear of being blamed for keeping it a secret. The same thing was obtained in Sun's research, that more participants decided to be open about their status than to keep it a secret (W. Sun et al., 2020).

In this study, both stigmatized and non-stigmatized informants received support from family, neighbors, colleagues, religious leaders, and the community. Friends and family are the main source of support received during the informant's healing period. This is probably due to the close family ties of the Indonesian people. Ozmet's research also states that the source of support from family and friends during the quarantine period is higher than other sources of support (Özmete \& Pak, 2020). Social support from families can reduce negative emotions and provide opportunities to share feelings with each other during the COVID-19 pandemic (El-Zoghby, Soltan, \& Salama, 2020). In addition, from the results of research on SARS survivors, support from family and friends has a greater impact in overcoming distress due to the condition they were experiencing (Mak et al., 2009).

In this study, religious leaders also played a major role in persuading the public to accept the presence of COVID-19 survivors in their living areas by providing information about COVID-19 through mosque forums. Religious leaders and institutions play an vital role in providing social support by providing health information (Weinberger-Litman, Litman, Rosen, Rosmarin, \& Rosenzweig, 2020). Boru stated that apart from health workers, the involvement of religious leaders and traditional healers in educating is needed to consider the causes of the non-disclosure of TB status in Southern Ethiopia (Gugssa Boru, Shimels, \& Bilal, 2017).

Social support from the community, in this case, neighbors, was not much found in the case of informants who experienced stigma. On the other hand, informants who did not receive the stigma felt that they received great social support from the community. Previously, informants were worried that they would be stigmatized after reporting positive status for COVID-19 to 
International Journal of Innovation, Creativity and Change. www.ijicc.net

Volume 15, Issue 9, 2021

local community chief. However, it turned out that almost all residents provided moral and material support to the informants. Because most of the neighbors in the neighborhood provide support, those who have a negative stigma do not show it directly to informants so that informants do not feel stigmatized.

The social stigma experienced by informants comes from the community, therefore involving the community can be used as a strategy to overcome stigma so that it can accelerate COVID-19 survivors to be able to reintegrate into society (Dar et al., 2020). The social support received can reduce or even eliminate the stigma received by informants. Li's research results show that the impact of stigmatization in the form of shame, anxiety, and depression is significantly lost when social support is high (J. Li et al., 2020).

The results showed that the role of society was substantial in the emergence of stigma. Compared to the stigma from society, the stigma that comes from family and friends is not high. On the other hand, from the case of this research, when the community together provides social support, the risk of stigma can be reduced or even completely eliminated. In addition, religious leaders, local community chief, and workplace leaders have an important role to play in reducing stigma. Social support from the community and government is more effective than social support from individuals (Song \& Yoo, 2020). Therefore social support from the community must be increased. Support from the public can be used to overcome stigma, as was done in Turkey by forming a "Loyalty Support Group", as social support during the COVID-19 pandemic (Özmete $\&$ Pak, 2020). Thus, the results of this study can be used to prevent stigmatizing behavior by strengthening social support, especially community support.

\section{Conclusion}

In the COVID-19 new normal period, uncertainty regarding the treatment and prevention of disease is still considerable. The stigma associated with COVID-19 remain strong. Stigma is not only experienced by positive COVID-19 informants but also people around them. From this study, it can be seen that social support can help reduce stigma. Social support that comes from the community is the most influential in reducing stigma. When the community provides support together, informants tend not to stigmatized. Therefore social support from the community must be increased to eliminate the stigma.

\section{Acknowledgment}

The authors would like to thank the Head of The National Institute of Health Research and Development and The Magelang Health Research and Development Center for all the support given. We also thank all respondents who participated in this research. 
International Journal of Innovation, Creativity and Change. www.ijicc.net

Volume 15, Issue 9, 2021

\section{Reference}

Abuhammad, S., Alzoubi, K., \& Khabour, O. (2020). Fear of COVID-19 and stigmatization toward infected people among Jordanian people. Int J Clin Pract, O0(e13899), 1-7. https://doi.org/https://doi.org/10.1111/ijcp.13899

Amo-Adjei, J. (2016). Individual, household and community level factors associated with keeping tuberculosis status secret in Ghana. BMC Public Health, 16(1), 1-9. https://doi.org/10.1186/s12889-016-3842-y

Bhatt, N., Bhatt, B., Gurung, S., Dahal, S., Jaishi, A. R., Neupane, B., \& Budhathoki, S. S. (2020). Perceptions and experiences of the public regarding the COVID-19 pandemic in Nepal: A qualitative study using phenomenological analysis. BMJ Open, 10(12), 1-11. https://doi.org/10.1136/bmjopen-2020-043312

Brewis, A., Wutich, A., \& Mahdavi, P. (2020). Stigma, Pandemics, and Human Biology: Looking Back, Looking Forward. American Journal of Human Biology, 32(5), 1-7. https://doi.org/10.1002/ajhb.23480

Brooks, S. K., Webster, R. K., Smith, L. E., Woodland, L., Wessely, S., Greenberg, N., \& Rubin, G. J. (2020). Rapid Review The Psychological Impact of Quarantine and How to Reduce it : Rapid Review of the Evidence. The Lancet, 395(10227), 912-920. https://doi.org/10.1016/S0140-6736(20)30460-8

Centers for Disease Control and Prevention. (2020). Reducing Stigma. Retrieved March 25, 2020, from https://www.cdc.gov/coronavirus/2019- ncov/daily-life-coping/reducingstigma.html.

Dar, S. A., Khurshid, S. Q., Wani, Z. A., Khanam, A., Haq, I., Shah, N. N., .. Mustafa, H. (2020). Stigma in coronavirus disease-19 survivors in Kashmir, India: A cross-sectional exploratory study. PLoS ONE, 15(11), 1-14. https://doi.org/10.1371/journal.pone.0240152

Dye, T. D., Alcantara, L., Siddiqi, S., Barbosu, M., Sharma, S., Panko, T., \& Pressman, E. (2020). Risk of COVID-19-related bullying, harassment and stigma among healthcare workers: An analytical cross-sectional global study. BMJ Open, 10(12), 1-15. https://doi.org/10.1136/bmjopen-2020-046620

El-Zoghby, S. M., Soltan, E. M., \& Salama, H. M. (2020). Impact of the COVID-19 Pandemic on Mental Health and Social Support among Adult Egyptians. Journal of Community Health, 45(4), 689-695. https://doi.org/10.1007/s10900-020-00853-5

Fawaz, M., \& Samaha, A. (2020). The psychosocial effects of being quarantined following exposure to COVID-19: A qualitative study of Lebanese health care workers. International Journal of Social Psychiatry, 66(6), 560-565. https://doi.org/10.1177/0020764020932202

Grover, S., Singh, P., Sahoo, S., \& Mehra, A. (2020). Stigma related to COVID-19 infection: Are the health care workers stigmatizing their own colleagues? Asian Journal of Psychiatry, 53(102381), 1-2. https://doi.org/doi: 10.1016/j.ajp.2020.102381

Gugssa Boru, C., Shimels, T., \& Bilal, A. I. (2017). Factors contributing to non-adherence with 
International Journal of Innovation, Creativity and Change. www.ijicc.net

Volume 15, Issue 9, 2021

treatment among TB patients in Sodo Woreda, Gurage Zone, Southern Ethiopia: A qualitative study. Journal of Infection and Public Health, 10(5), 527-533. https://doi.org/10.1016/j.jiph.2016.11.018

Imran, N., Afzal, H., Aamer, I., Hashmi, A., Shabbir, B., Asif, A., \& Farooq, S. (2020). Scarlett letter: A study based on experience of stigma by COVID-19 patients in quarantine. Pakistan Journal of Medical Sciences, 36(7), 1471-1477. https://doi.org/10.12669/pjms.36.7.3606

Janitra, F., Melastuti, E., Yusuf, A., Fadhilah, H., \& Wibawa, Y. (2021). Perceived Stigma, Psychological Response, And Nurse Coping In The Covid-19 Pandemic In Indonesia. Jurnal Keperawatan Padjajaran, 9(1), 10-17.

Kompas. (2020). Rawat Pasien Covid-19, Tenaga Medis Diusir dari Kos hingga Harus Menginap. $\quad$ Retrieved March 25, 2020, from https://megapolitan.kompas.com/read/2020/03/25/14090911/rawat-pasien-covid-19tenaga-medis-diusir-dari-kos-hingga-harus-menginap?page=all.

Li, H., Zheng, L., Le, H., Zhuo, L., Wu, Q., Ma, G., \& Tao, H. (2020). The mediating role of internalized stigma and shame on the relationship between covid-19 related discrimination and mental health outcomes among back-to-school students in Wuhan. International Journal of Environmental Research and Public Health, 17(24), 1-14. https://doi.org/10.3390/ijerph17249237

Li, J., Liang, W., Yuan, B., \& Zeng, G. (2020). Internalized stigmatization, social support, and individual mental health problems in the public health crisis. International Journal of Environmental Research and Public Health, 17(12), 1-14. https://doi.org/10.3390/ijerph17124507

Mak, W. W. S., Law, R. W., Woo, J., Cheung, F. M., Lee, D., Mak, W. W. S., ... Lee, D. (2009). Social support and psychological adjustment to SARS: The mediating role of self-care self-efficacy. Psychology and Health, 24(2), 161-174. https://doi.org/10.1080/08870440701447649

Özmete, E., \& Pak, M. (2020). The Relationship between Anxiety Levels and Perceived Social Support during the Pandemic of COVID-19 in Turkey. Social Work in Public Health, 35(7), 603-616. https://doi.org/10.1080/19371918.2020.1808144

Saeed, F., Mihan, R., Mousavi, S. Z., Reniers, R. L. E. P., Bateni, F. S., Alikhani, R., \& Mousavi, S. B. (2020). A Narrative Review of Stigma Related to Infectious Disease Outbreaks: What Can Be Learned in the Face of the Covid-19 Pandemic? Frontiers in Psychiatry, 11(December), 1-8. https://doi.org/10.3389/fpsyt.2020.565919

Satgas Penanganan COVID-19. (2020). No Title. Retrieved from https://covid19.go.id/

Schmitt, M. T., Branscombe, N. R., Postmes, T., \& Garcia, A. (2014). The consequences of perceived discrimination for psychological well-being: a meta-analytic review. Psychol Bull, 140(4), 921-948. https://doi.org/10.1037/a0035754 
International Journal of Innovation, Creativity and Change. www.ijicc.net Volume 15, Issue 9, 2021

Song, E., \& Yoo, H. J. (2020). Impact of social support and social trust on public viral risk response: A COVID-19 survey study. International Journal of Environmental Research and Public Health, 17(18), 1-14. https://doi.org/10.3390/ijerph17186589

Sulistiadi, W., Rahayu, S., \& Harmani, N. (2020). Handling of Public Stigma on COVID-19 in Indonesian Society. Kesmas, 1, 70-76. https://doi.org/10.21109/kesmas.v15i2.3909

Sun, N., Wei, L., Wang, H., Wang, X., Gao, M., Hu, X., \& Shi, S. (2021). Qualitative study of the psychological experience of COVID-19 patients during hospitalization. Journal of Affective Disorders, 278(24), 15-22. https://doi.org/10.1016/j.jad.2020.08.040

Sun, S., Goldberg, S. B., Lin, D., Qiao, S., \& Operario, D. (2021). Psychiatric symptoms, risk, and protective factors among university students in quarantine during the COVID-19 pandemic in China. Globalization and Health, 17(1), 1-14. https://doi.org/10.1186/s12992021-00663-X

Sun, W., Zhou, Y., Chen, W. T., Huang, F., Sun, M., Shen, L., ... Lu, H. (2020). Disclosure experience among COVID-19-confirmed patients in China: A qualitative study. Journal of Clinical Nursing. https://doi.org/10.1111/jocn.15616

Turner-Musa, J., Ajayi, O., \& Kemp, L. (2020). Examining Social Determinants of Health, Stigma, and COVID-19 Disparities. Healthcare, 8(2), 168. https://doi.org/10.3390/healthcare8020168

Weinberger-Litman, S. L., Litman, L., Rosen, Z., Rosmarin, D. H., \& Rosenzweig, C. (2020). A Look at the First Quarantined Community in the USA: Response of Religious Communal Organizations and Implications for Public Health During the COVID-19 Pandemic. Journal of Religion and Health, 59(5), 2269-2282. https://doi.org/10.1007/s10943-02001064-X

WHO. (2020). WHO Coronavirus Disease (COVID-19) Dashboard. Retrieved from https://covid19.who.int/table 